Journal of Economics and Policy

http://journal.unnes.ac.id/nju/index.php/jejak

\title{
Factors Affecting the Domestic Price of Rice in Indonesia
}

\author{
Wawan Hermawan ${ }^{\bowtie}$, Fitrawaty $^{2}$, Indra Maipita ${ }^{3}$ \\ 'Faculty of Economic and Business Padjadjaran University \\ 2,3Faculty of Economic State University of Medan \\ Permalink/DOI: http://dx.doi.org/10.15294/jejak.v1oi1.9133 \\ Received:August 2016; Accepted: November 2016; Published: March 2017
}

\begin{abstract}
This study aims to determine the factors that have dominant influence to domestic prices of rice. Ordinary Least Square is used to run model with time series data from BPS. The results of the study we found that domestic rice production and the exchange rate have negative effect on domestic rice prices, in contrast the international rice price and the level of income per capita. Domestic production of rice and international prices of rice do not significantly affect domestic prices of rice, while the exchange rate and per capita income significantly affect domestic prices of rice respectively at the alpha level of 10 and 1 percent. Per capita income is a the greatest influence on the formation of domestic prices of rice by the estimated coefficient of 3.5985. This condition also describe the level of society's dependence on rice consumption. The high of difference of domestic price of rice with the international rice prices can be detrimental to the community while providing a strong emphasis on increasing imports of rice as well as trigger the illegal market.
\end{abstract}

Key words : Domestic price of rice, exchange rate, Income.

How to Cite: Hermawan, W., Fitrawaty, F., \& Maipita, I. (2017). Factors Affecting the Domestic Price of Rice in Indonesia. JEJAK: Jurnal Ekonomi Dan Kebijakan, 10(1), 155-171. doi:http://dx.doi.org/10.15294/jejak.v1oi1.9133

\begin{tabular}{ll}
\hline Corresponding author: & p-ISSN 1979-715X \\
Address: FE Universitas Negeri Medan, Jl. W. Iskandar Ps.V & e-ISSN 2460-5123 \\
Medan & \\
E-mail: imaipita@gmail.com &
\end{tabular}




\section{INTRODUCTION}

Indonesia has undergone a structural change of the economy since the 196os. Indonesia shifted from agricultural economic structure to structure-based industries. Contribution of the agricultural sector is greater than 50 percent of Indonesia's GDP up to 1967 . Beginning in 1968 , the agricultural sector's contribution to GDP has a tendency to continue to fall until 2015. Figure 1 shows the contribution of agriculture sector to GDP Indonesia at current prices. Trends in agricultural sector contribution to GDP continues to decline indicates an increase in output in sectors other than agriculture. In 1998 Indonesia experienced a severe economic crisis. Economic growth fell 13.1 percent, but the agricultural sector to grow faster than usual. Agricultural sector's contribution to GDP in 1998 grew significantly. One of the best sector to face the crisis in 1998 is agriculture sector. Agriculture sector lead the economy to make Indonesian move up and still get the positive growth in
Indonesian economy.

Changes in economic structure can also be seen from the main job of changes. The agricultural sector absorbing labor up to 74 percent in 1960. In 2015, employment in the agricultural sector only reached 32.88 percent. Figure 2 shows the decline in employment in the agriculture sector in Indonesia in 1960 until 2015. There was a shift in employment in other sectors, in addition to the agricultural sector. This is understandable, value added in the agriculture sector in addition to the larger and more sectors that could get added value in a short time compared with the agricultural sector. The transfer of human resources to other sectors, which fell by percentage, but sufficiently offset by growth in population. However, the additional amount of work in the agricultural sector is not as big as the additional number of people working in non-agricultural sectors. It is still in accordance with the amount of agricultural land are likely to remain, or much change in land use to be a function other than for agriculture.

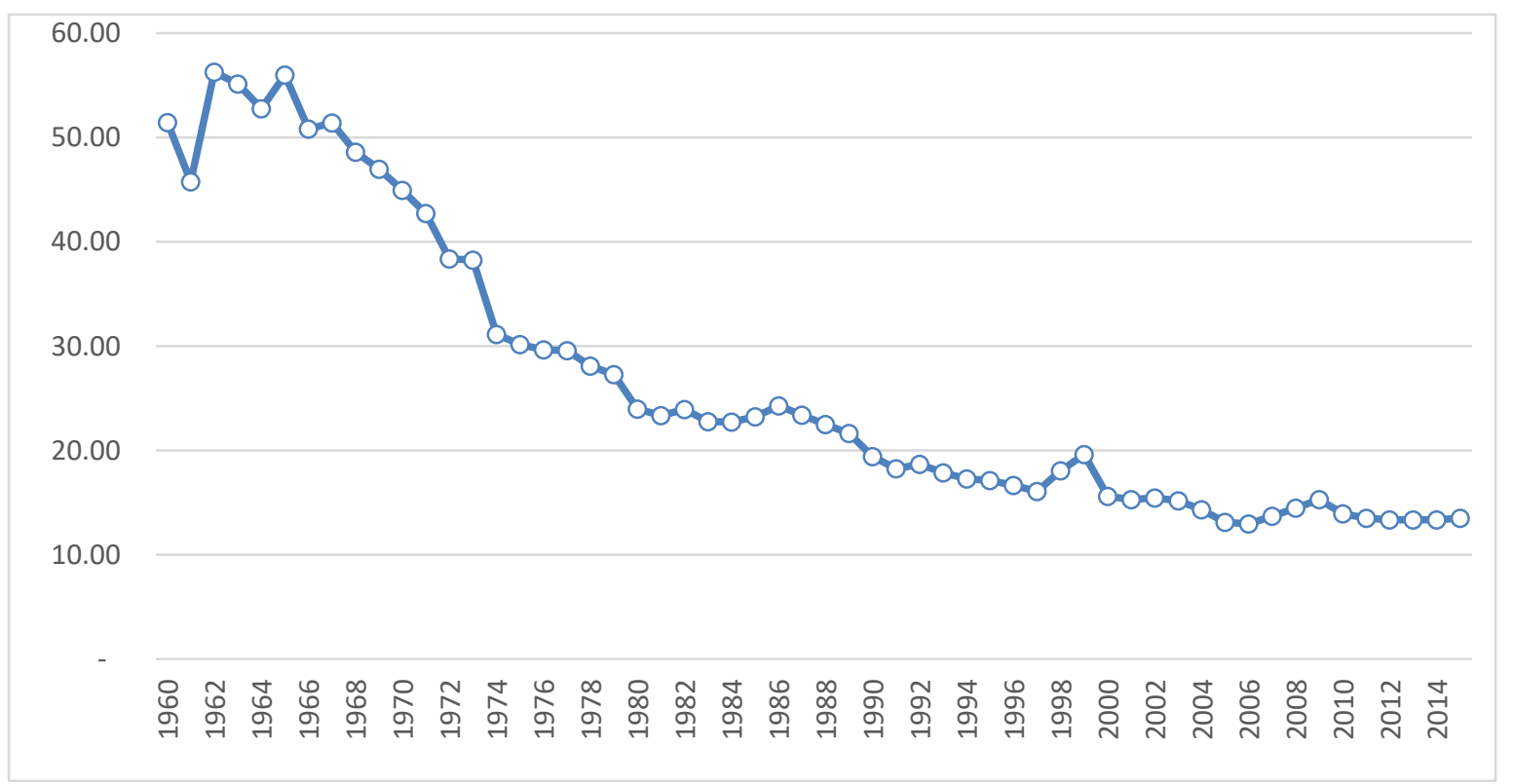

Source: BPS

Figure 1. Share of Agriculture Sector to GDP at Current Prices (\%). 


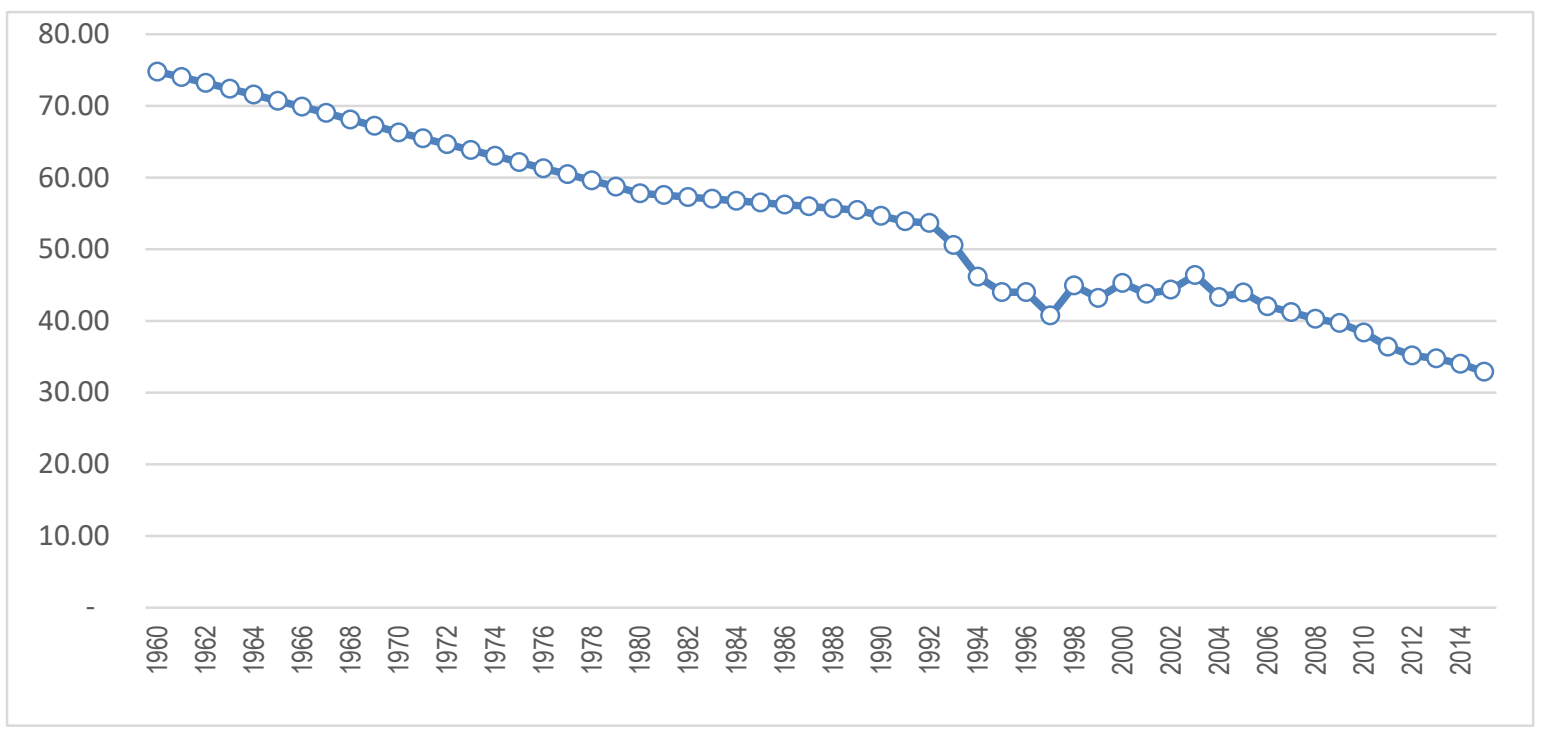

Source: BPS

Figure 2. People Working In The Agricultural Sector (\%).

Economic development is done by emphasizing the development of the agricultural sector. Strengthening the agricultural sector continues to be done during the five-year development (PELITA) in the era of the Orde Baru regime, led by the second president of the Republic of Indonesia, Soeharto. The golden age of this era, Indonesia experienced a period of food selfsufficiency (Swasembada Pangan) that President Soeharto was named the Father of Development. Strengthening the agricultural sector continued to drive economic development based industrial sector. The era of modern development that is expected to occur at the time of Indonesia has a strong industrial sector.

Changing economic structure seen from the agricultural sector's contribution to GDP and employment in agriculture and nonagriculture has changed the pattern of household consumption expenditure. Percentage of Average Expenditure per Capita per month According to the Group of which is divided into two large, namely the expenditure for food and non-food expenditure. The percentage of average expenditure per capita in 1999 to reach $62.94 \%$ of food spending, in the following years there was a tendency down the composition of expenditures for food. In contrast, spending on non-food increased composition of 1999 which only amounted to 37.06 percent to 53.55 percent in 2015. Figure 3 shows the trend of expenditure for food continue to fall throughout the year 19992014.

Most of the Indonesian expenditure per capita still expend for food (Figure 3), Food is a primary need that must be met to make people survive (Widayaningsih and Barokatumunalloh, 2016). Despite the declining trend, from 1999 to 2014 the share of expenditure on food is still above 40 per cent of the total expenditure made. This expenditure profile shows the elasticity of the food items are still not income elastic.

Rice is the staple food for most of the Indonesia people, and more than 95 percent of Indonesia still relies on rice as a staple food. These conditions resulted in the price of rice is the benchmark of various economic indicators. Purchasing power of food shows the level of welfare of society. 


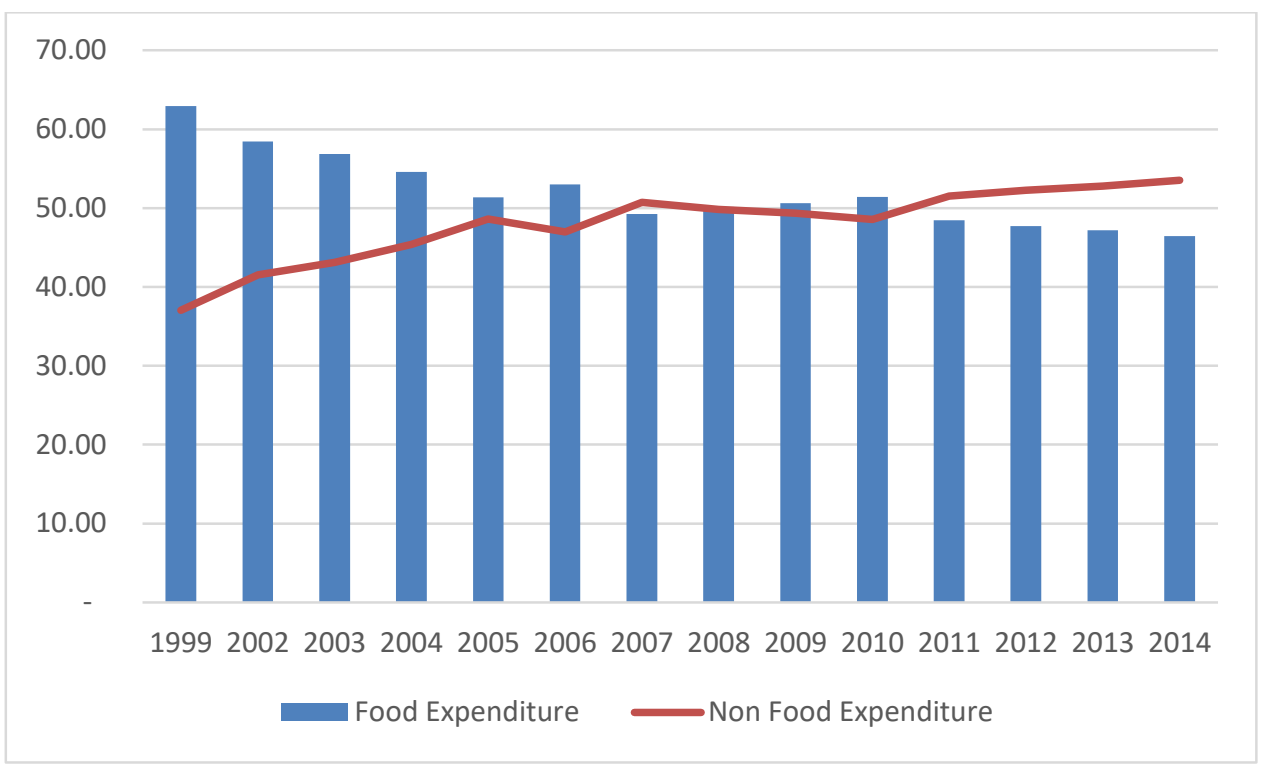

Source: BPS

Figure 3. Percentage of Average Expenditure per Capita per Month by Type of Expenditure

Rice consumption is a major commodity in the calculation of commodity packages of food needs by BPS (Maipita, 2014). In addition, rice is the main commodity and has a big influence to the poverty line (CBS, 2013). This is due to the poor, fulfilling the needs for survival becomes the primary. Spending on food is a priority can even spend all the income of a head of household. If spending on food is reduced, meaning that can meet the spending on clothing and other primary expenditure. At the time this happens, then an increase in welfare for a family.

When we look at the movement of the price of rice in the Indonesia from January to April 2015, the price looks fluctuate as shown in Figure 4. Fluctuations in the price of rice will have an impact on people's purchasing power (Shrestha, and Chaudhary, 2012), and ultimately impact on poverty levels. When the price of rice increased, the share of income spent on food (rice) will also be increased (De Hoyos and Medvedev, 2009). People who are slightly above the poverty line will be able to fall below the poverty line. The increase in rice prices have a large impact on the increasing contribution of food expenditure of total family income. The fulfillment of primary needs, such as for clothing and expenditure on health will lose priority to food expenditures. Impact of derivatives by increasing the number of poor people.

Fluctuations of the price of rice in Indonesia is the caused by many things, for example: (1) structural factors and cycles, (2) factors of supply and demand, (3) international and domestic markets (ADB, 2008), (4) climate, (5) distribution, (6) the exchange rate, and more. The period of the rice harvest are factors that play a great role in price changes. Much of supply of rice were great at providing a decrease in the price of rice, so that rice prices could fall due to an oversupply. The price of rice in Indonesia was also affected by some of the policies of the Ministry of Agriculture and the President's policy in influencing the stock and the price of rice in Indonesia. Rice import policy is a policy for the reduction in the price of rice with the flood of supply of rice which cost less than the market price. 


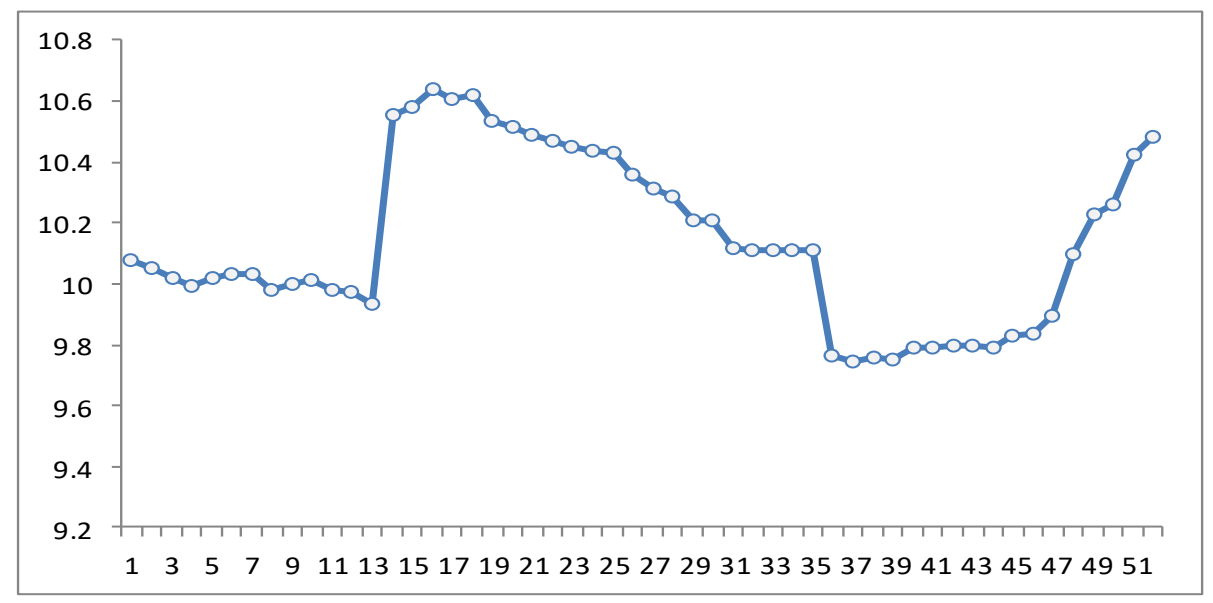

Souce : BPS

Figure 4. The Trend Movement of Price of Rice in medium January-April 2015 (Rp/Kg).

The amount of family spending on consumption is influenced by many factors, such as: the level of income, level of prices, interest rates, and expectations for the future. According to the theory of Keynes' consumption, the consumption level is strongly influenced by a person's income level. That is, when prices rise, the purchasing power is going down because the amount of money that must be spent to maintain the same level of consumption should increase. When the level of fixed and limited income, the amount of goods consumed should be reduced. Reduction of purchasing power and consumption will reduce the level of social welfare. For people who are slightly above the poverty line, this condition can shift them below the poverty line. When this happens, the poverty rate would increase.

Poverty is still a crucial issue and a very complex phenomenon to any country (Hung and Makdissi, 2004; Marianti and Munawar 2006; Maipita et al, 2010, 2014, 2016; Jantan et al 2012). Even Poverty Alleviation has been the primary goal of public policy in almost all industrialized countries (Moller, et al, 2003). Empirical evidence from various studies indicate that the rice price increase will have an impact on the purchasing power, poverty and inequality (Shrestha, and Chaudhary, 2012; De Hoyos and Medvedev, 2009; World Bank, 2008; Save the Children, 2009; Ravalion and Walle, 1991; Minot and Goletti, 2000).

On the other hand, Indonesia was in a condition known as "demographic bonus" (MP3EI, 2011; Maipita, 2014). The dependency ratio is relatively small. This means that at this time until the next few decades Indonesia has the working age population is quite large compared with children and old age. Increasing the working age population indicates that there will be an increase in consumption. The consumption of productive age will be higher than people who are not productive. This means that the demand for rice as a staple food of Indonesian society will also increase.

\section{RESEARCH METHODS}

The demand for rice in the form of the function of the price, is influenced by the price of the rice itself and the level of income. In other words, the demand for rice is affected by price and income levels. However, for the case of rice in Indonesia, the prices are very influenced by harvest or production of rice in domestic and 
international rice prices. This is because Indonesia still require imports to keep domestic demand for rice. Therefore, in theory, the exchange rate also affect the price formation. Thus, the price of domestic rice equations used in this study is written as equation (1).

$\ln P d_{t}=a+b_{1} \ln Q_{t}+b_{2} \ln e_{t}+b_{3} \ln P_{t}^{*}+$ $\ln G D P K_{t}+u_{t}$

Where :

Pd : The price of domestic rice

Q : Rice Production

e : Exchange rate (RP/US\$)

$\mathrm{P}^{*} \quad$ : International price of rice

GDPK : GDP per capita

$\mathrm{t}$ : Year

The model in equation (1) is useful to get the behavior of the price of rice by using annual data from 2000 to 2014. The estimated coefficients of equation (1) will give an overview of the behavior (business as usual) on changes in independent variables, namely production rice, exchange rate, international prices and per capita income. Furthermore, the simulation of the significant variables by raising and lowering the value of the value of each variable (in percent) each year from 2015 to 2020 with a baseline year 2014. Furthermore, we will see the impact of each simulation of the domestic rice price. The value obtained from the simulation of the geometric mean of the growth of each variable during the years 2000-2014.

\section{RESULTS AND DISCUSSION}

\section{Domestic Price Rice Pattern}

ASEAN member countries plays an important role in world rice trade. ASEAN member countries are largely a producer (exports) rice except Indonesia and the Philippines (net imports). Approximately 53 percent of total exports and 19 percent of total imports and 22 percent of total world rice consumption is done by the member countries of ASEAN (Wailes and Chaves, 2012). The data of rice production and consumption of the 10 member countries of ASEAN by the year 2022 are shown in Table 1.

Rice producer in ASEAN as well as India, Pakistan, and the United States play an important role in determining the international rice prices. The period 2000 to 2014 , rice price movements both domestic prices and international prices tend to rise as shown in Figure 5. Furthermore it appears that there is a relatively large difference between the prices of domestic rice premises international rice prices for average quality rice. Economically, these conditions lead to export as well as because it is needed for domestic demanders higher than the existing production.

In 2000, domestic rice prices are relatively cheaper than the international price of rice, but the condition is changing as domestic rice prices kept rising rapidly exceeds the rate of rise in international rice prices, so that the difference between the two prices as convergent farther away. In 2010-2014, the domestic price of rice is estimated at about 60 percent more expensive than the price of international rice (World Bank, 2010; Timmer, 2014; OECD, 2015). This indicates that the imported rice will put an emphasis on domestic rice prices. According to the study of the OECD, that the high price of rice domestic than the international rice prices caused by several things, among the policy of restrictions on imports of rice, and the condition is detrimental to the Indonesian people, especially the poor, who are largely portion of expenditures used to purchase rice (OECD, 2015; World Bank, 2010). In addition, the government is also required to ensure the right to food of every citizen by ensuring adequacy and affordability for the survival of citizens (Syaifullah, 2013). 
Table 1. Total Rice Supply and Utilization of 10 ASEAN Countries 2010-2022

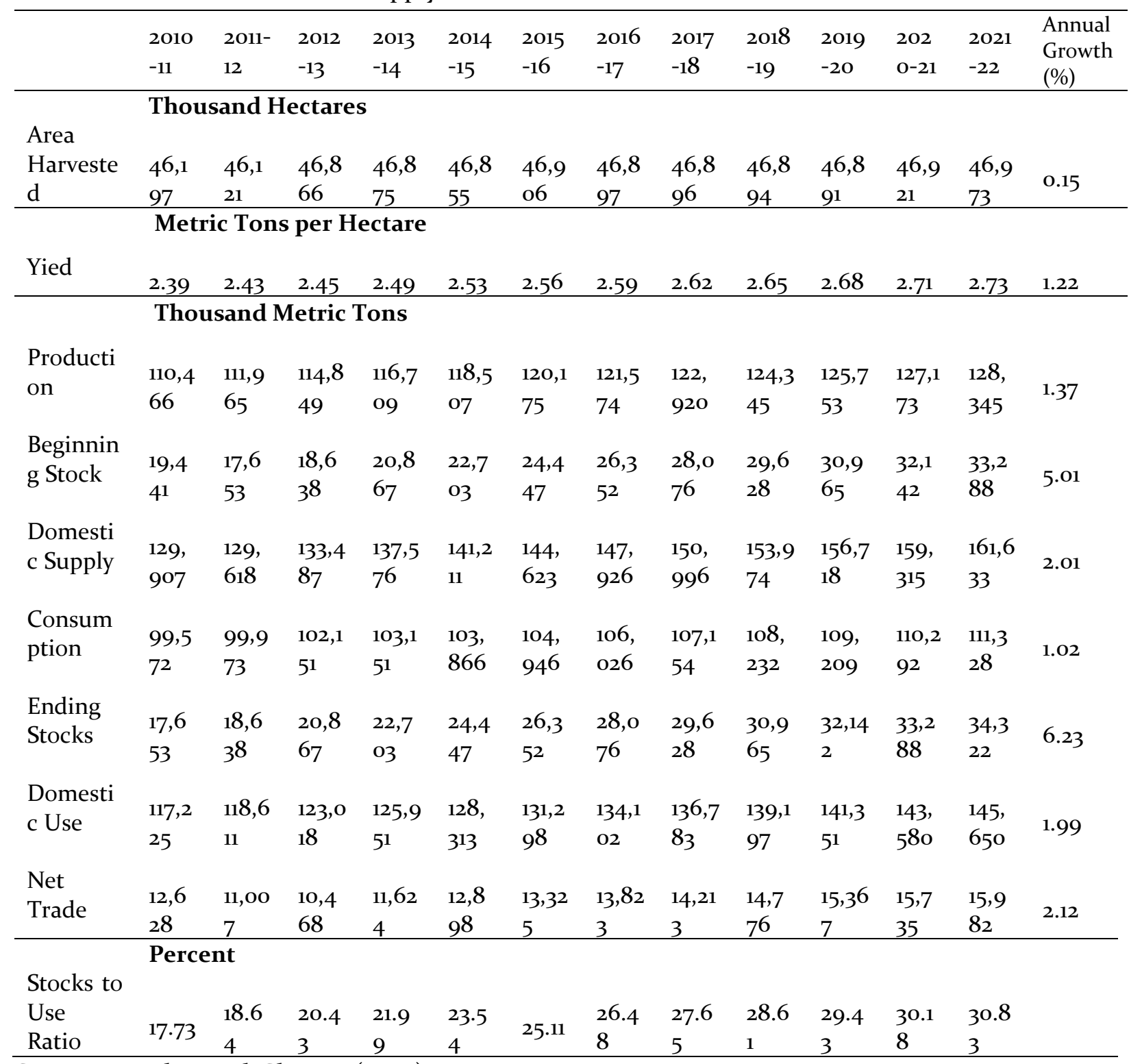

Source: Wailes and Chaves (2012).

The higher the difference between the price of domestic rice at an international rice prices on the one hand more and trigger an increase in imports and this would be detrimental to domestic farmers. While on the other hand, policies that restrict imports of rice would be detrimental to the public because they have to pay a higher price than the world market price, in addition also will trigger a black market (smuggling).
As presented in equation (1), that the domestic price of rice is affected by many variables, namely domestic rice production, exchange rates, international rice prices, and per capita income levels of society (in this case measured by GDP per capita). To see the characteristics of those variables, were estimated to equation (1). Summary of Estimated results are shown in Table 2. 


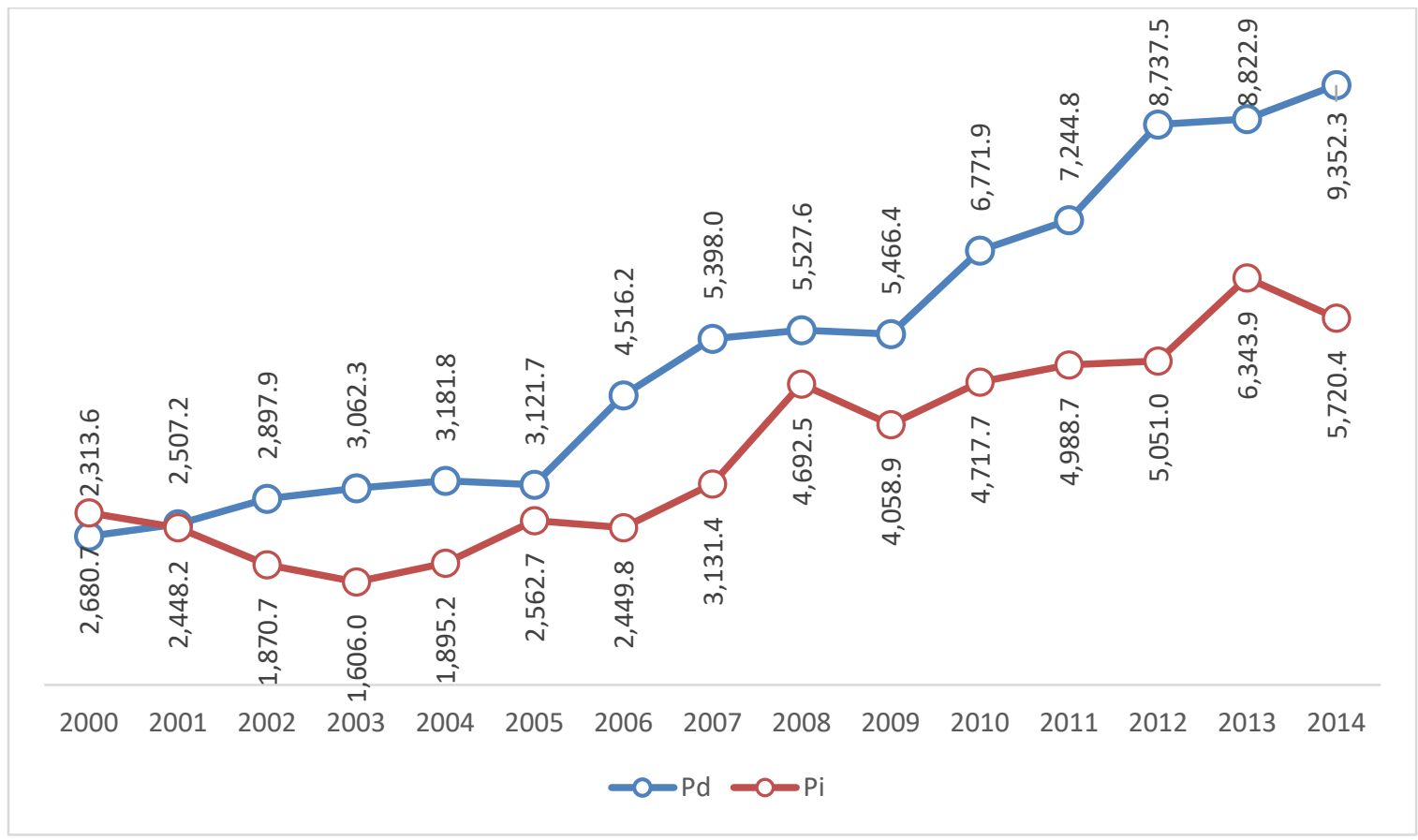

Source: BPS calculated; Pd = The Domestic Price of Rice, $\mathrm{Pi}=$ The International Price of Rice Figure 5. The Domestic Price of Rice and International Price of Rice (USD / kg) with average Quality.

From Table 2 and equation ( 2 ) note that domestic rice production variables did not significantly influence the price of domestic rice. In other words, the period of 2000-2014, regardless of the number of domestic rice production is not able to significantly influence the price of rice in the country. This is due to several things, such as: (1) during the period of study, the number of domestic rice production is too little compared to the needs that cannot affect the stock of rice which eventually also unable to influence the price, (2) although the harvest occurs, decrease price only occur at the farm level, namely in the form of a decrease in grain prices, but the price of rice in general in society tend to have no effect, (3) to fulfill the lack of rice supply (meet demand) is done by rice imports at more competitive prices (lower), (4) system guarantees the price of grain at the farm level has not been done optimally, (5) the level of efficiency of rice production is still low, (6) Indonesia's position as a net importer of rice (Wailes and Chaves, 2012), (7) rice not only serves as consumption and social interests, but also as a political consumption (Ministry RI, 2015a), (8) infrastructure that rice production has not been optimized resulting in high cost of production and distribution becomes uneven.

From the estimation results in Table 2 was obtained domestic rice price equation as shown in equation (2).

$\ln P d_{t}=21.87996-0.9761 \ln Q_{t}-0.5092 \ln e_{t}+0.04456 \ln P_{t}^{*}+3.5985 \ln G D P K_{t}$ (*) $(* * *)$

$\mathrm{R}^{2}=0.9821 ; *: \operatorname{Sig} \alpha=10 \% ;{ }^{* * *}: \operatorname{Sig} \alpha=1 \%$ 
Table 2. Estimation Results of Domestic Price of Rice

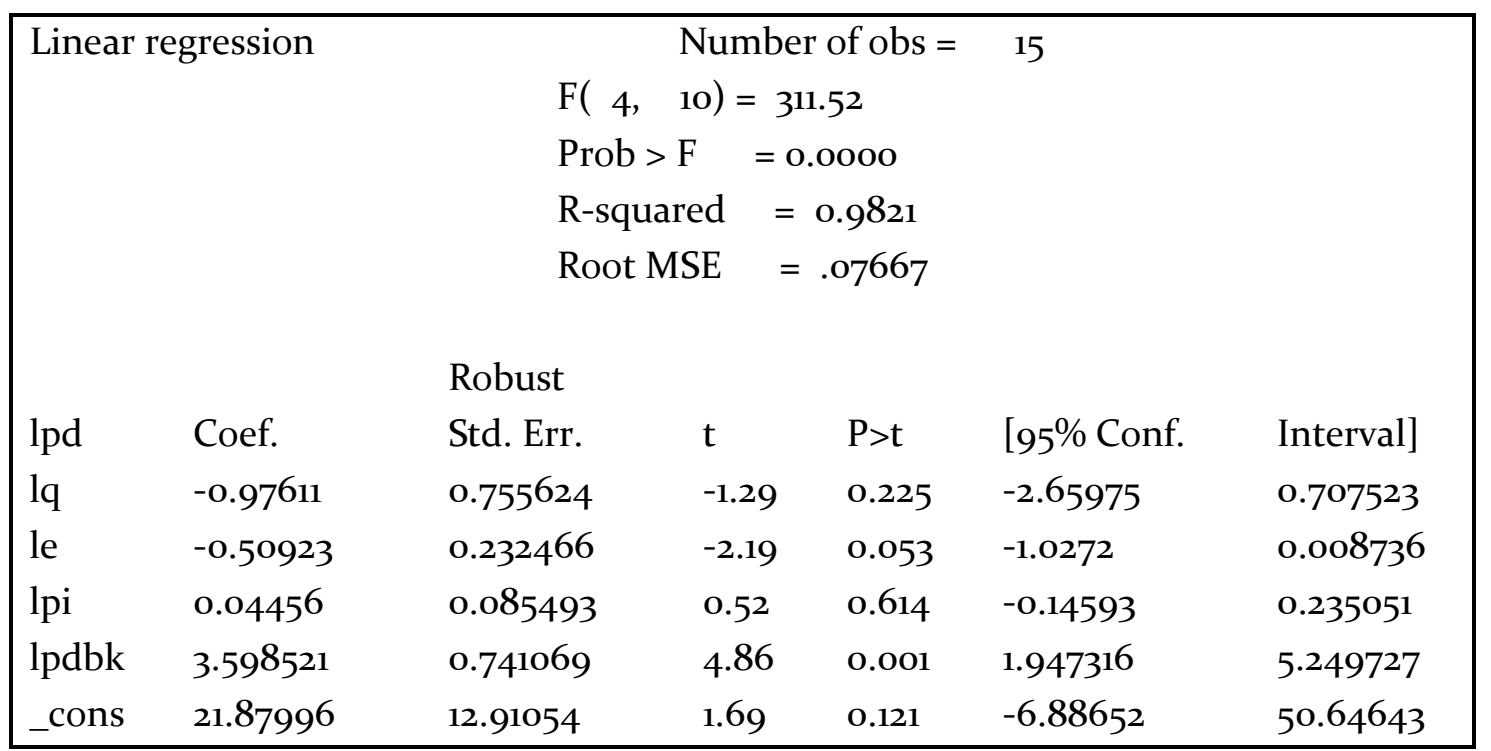

The sign of the coefficients in equation (2), it is known that variable of domestic rice production (domestic), and the exchange rate have negative effect on domestic prices of rice, while international prices of rice and the level of per capita income of the people have positive influence on the price of domestic rice. This means that if there is an increase in domestic production and if there is an increase the value of Exchange Rate ( $\mathrm{Rp} /$ USD), then the domestic price will decline, and vice versa. Meanwhile, when international prices of rice and rising per capita income levels, it can push up domestic prices of rice. The signs of negative coefficient rice production may mean that if there is an increase rice production by one percent would reduce domestic rice prices by 0.98 percent. This figure is quite realistic although not significant at the alpha level of 10 percent.

It is interesting that although the international price of rice is much cheaper than domestic rice prices, but according to the results of the regression in equation (2), international rice prices do not significantly affect the price of domestic rice. This is due to government policies that restrict imports of rice so that even international rice prices are relatively low, but not necessarily be able to easily get into the country. Such a policy is relatively ineffective in protecting producers of rice (rice farmers) domestic (Bowo et al, 2016), but on the other hand could harm consumers because they have to buy at higher prices.

Various studies show that developing country imports from developing countries are largely influenced by changes in prices and exchange rates (exchange rate). Fluctuations in prices and exchange rates had a negative and significant effect on imports of agricultural products such as soybeans, corn and rice are imported from developing countries (Haque, 2012). This is due to limited access and trade policies such as restrictions on exports / imports (IFRI, 2011). Other researchers such as Kandilov (2008), Arize and Slottje (2008) also found similar negative effects.

Tables 2 and equation (2) shows that the variables that most influence on domestic rice prices are variable income levels (lnGDPKincome per capita), and a variable exchange rate (lne-Rp/USD), while the variable of domestic rice production and rice prices international 
does not significantly affect the price of rice in the country.

The rupiah exchange rate against the dollar showed a significant effect on the price of domestic rice. The coefficient value of 0.5092 indicates that when there is an increase of rupiah exchange rate against the dollar or a weakening rupiah against the dollar (depreciation) of one percent, then the domestic rice price will go down by $0.51 \%$. This contrasts with the theory that the increase in import prices should divert demand for domestic goods. This means that in this case the rise in import prices as a result of the depreciation of the rupiah is not the price of rice domestically to be cheaper than international rice prices, in other words, international prices of rice remain cheaper and demand for cheaper prices remain high.

These findings are in line with studies Tulasombat et al (2015) that the exchange rate affect the volume of foreign trade. The world trading system that is more open and the level of production in importing countries increasingly efficient cause the price of food products in the country are affected (Ministry of Trade of RI, 2015). Bowo et al (2016) conducted a study to test the competitiveness and government policies on rice, corn and soybean farming in Central Java province, found that profitability and competitiveness of farmers are sensitive to fluctuations in the exchange rate against the dollar and changes in international prices.

The behavior of the exchange rate of the domestic price of rice in line with the international price of rice variable. The increase in the international price, assuming constant exchange rates, shows the coefficient were positive but not significant in affecting change in the price of domestic rice. The coefficient of 0.05 indicates that changes in international prices of rice do not change the price of domestic rice.

The last variable is income per capita. This variable conveniently indicates that large and significant influence on price changes of domestic rice. If there is an increase in per capita income by one percent of domestic rice prices to be increased by 3.6 percent. This coefficients shows the high level of price elasticity of rice to per capita income (elastic). Although, according to the study Wailes and Chaves (2012) that supply of rice and demand are inelastic in the largely Asian countries.

This finding is consistent with the condition of Indonesian society that about 80 percent of the total population are consumers of rice and was ranked 5 th in the world for per capita consumption of rice calories (Ministry of Trade RI, 2015a). Over 50 per cent of the total expenditure of around half of Indonesia's population is used for food expenses, and approximately 17 percent of all spending for 20 percent of the lowest-income population used to consume rice (World Bank, 2010).

\section{Simulations}

Simulations carried out by trying to increase or decrease the variables that affect the domestic price of the above equation. The increase or decrease in the simulation is the geometric mean of the growth during the period 2000 to 2014. The simulations will be conducted by partial way in which only change one variable by increasing or decreasing the percentage change of each variable.

There are only two variables that significantly affect the price of rice, therefore the variables taken two of the four variables were estimated in equation (2). These variables are variable exchange rate and variable income per capita. Therefore, simulations were performed on these two variables. This method is used to make it easier for the simulation on a significant 
independent variables affect the dependent variable statistically. Other variables are assumed no change, so that impacts that occur only show the effect of one variable on the dependent variable.

The first simulation was done by raising and lowering the value of the rupiah against the dollar by \pm 1.87 percent per year from a year earlier. The value obtained from the simulation of the average geometric growth of these variables during the years 2000 to 2014 . The use of the geometric mean is taken to show the movement patterns of the average of the variable value of the rupiah against the dollar and the per capita income. The results of this simulation are shown in Table 3.

Generally, when the exchange rate increased (the value of the rupiah weakened or depreciated against the dollar), the decline of the domestic rice price. This condition is consistent with the findings in the estimation of equation (2). Although the impact of exchange rate changes on domestic rice prices is relatively small, but statistically significant according to equation (2).

The average of increase in the exchange rate of 1.87 percent per year from the previous year in 2020 , led to a decrease in the average domestic price of rice by 0.94 percent (an average of USD $88.79 / \mathrm{Kg}$ ). If the rise in the exchange rate per year occurred at 1.87 per cent until 2020, then the price of domestic rice in 2020 is estimated to be US \$9190.38 / kg, down from $\mathrm{Rp} 443.93$ / Kg of rice prices in 2015. Visually, the results simulating rise in exchange rate on the price of domestic rice shown in Figure 6.

Conversely, a decline in the rupiah against the dollar or rupiah appreciation, causing domestic rice prices tend to rise. This condition is shown in Figure 7, which shows a simulation in the event of a decrease in the exchange rate with other variables constant. This way to see the opposite effect of exchange rate movements on the domestic rice price.

Table 3. Simulation Results Increase and Decrease in Exchange Rate Against Domestic Rice Price

\begin{tabular}{|c|c|c|c|c|}
\hline \multicolumn{3}{|c|}{ Exchange Rate increase } & \multicolumn{2}{|c|}{ Exchange Rate decrease } \\
\hline Year & Pd (RP) & Growth $(\%)$ & Pd (RP) & Growth (\%) \\
\hline 2015 & $9634 \cdot 327$ & & 9819.595 & \\
\hline 2016 & 9543.858 & -0.9390 & 9914.443 & 0.9659 \\
\hline 2017 & 9454.238 & -0.9390 & 10010.21 & 0.9659 \\
\hline 2018 & 9365.461 & - 0.9390 & 10106.9 & 0.9659 \\
\hline 2019 & $9277 \cdot 516$ & - 0.9390 & $10204 \cdot 5^{2}$ & 0.9659 \\
\hline 2020 & 9190.398 & - 0.9390 & 10303.09 & 0.9659 \\
\hline
\end{tabular}

Source: Simulation Results. 


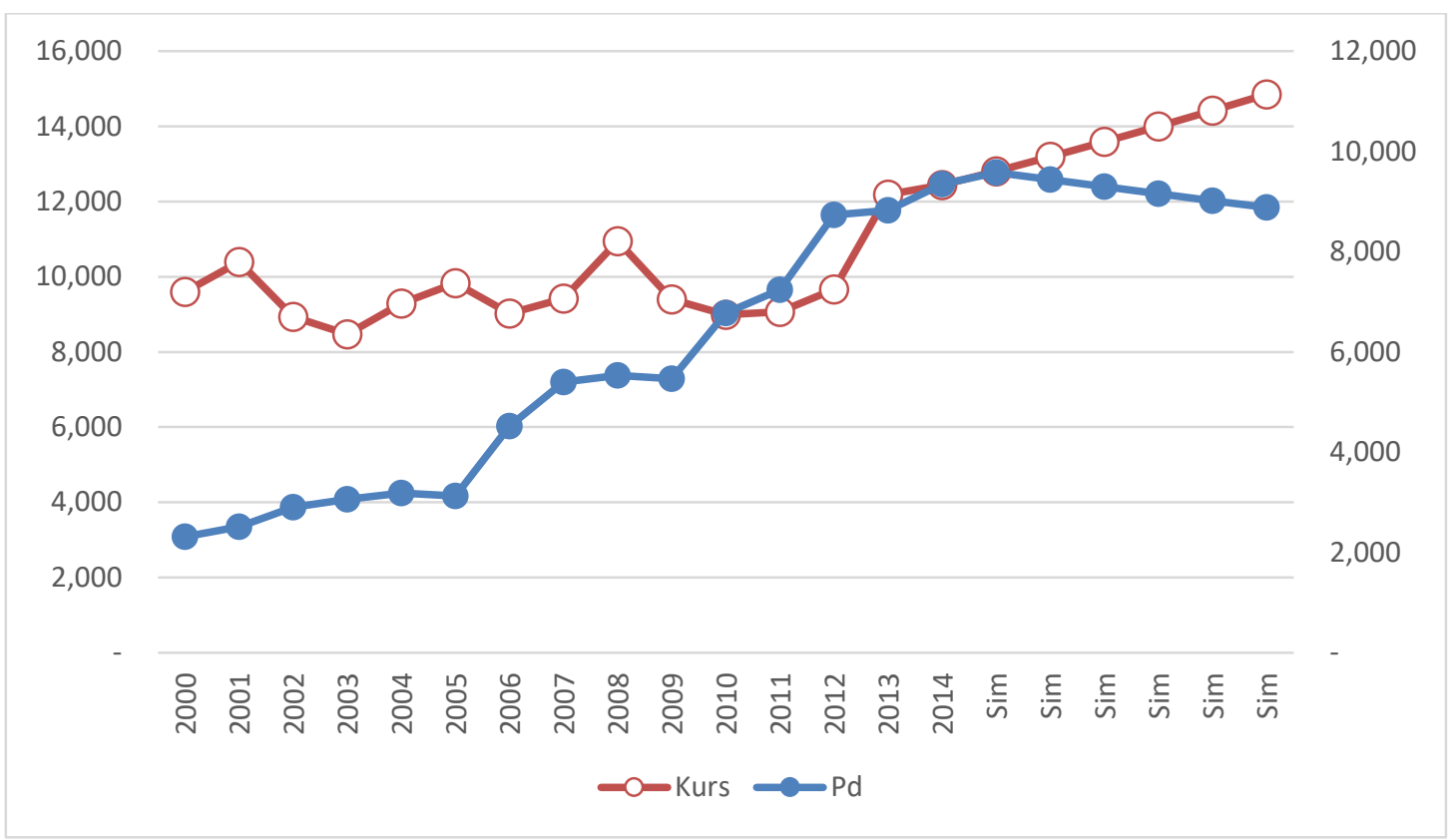

Source: Data Processing; (Kurs = Exchange Rate; $P_{d}=$ Domestic Rice Price)

Figure 6. Simulation Results Increase in Exchange Rate (US \$ / US \$) against Domestic Rice Price.

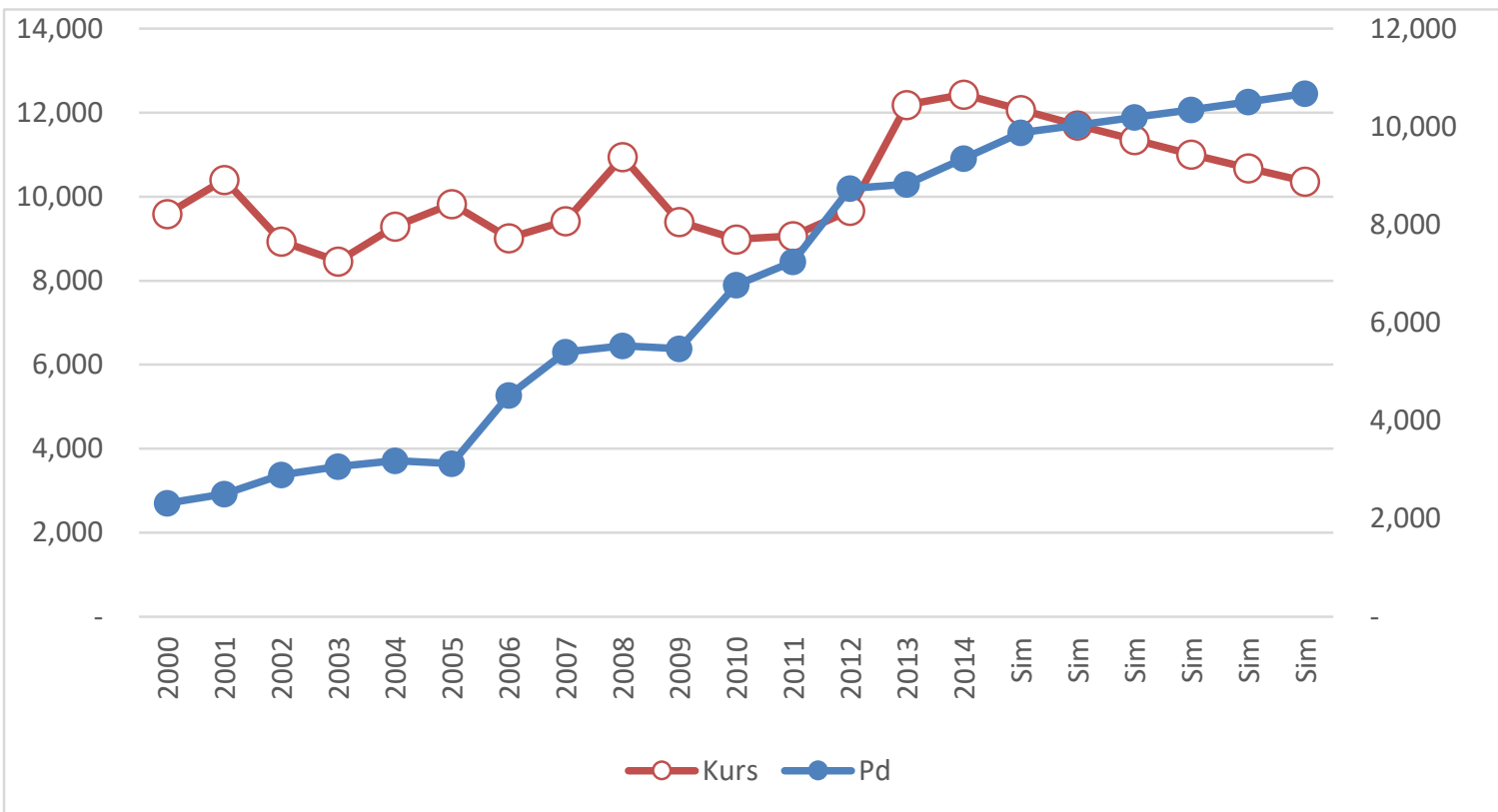

Source: Data Processing; (Kurs = Exchange Rate; Pd = The domestic rice price)

Figure 7. Simulation Results Decrease in Exchange Rate (US \$ / US \$) Against Domestic Rice Price

When a decline in the exchange rate is continuously at 1.87 percent per year, the price of rice will increase by an average of 0.97 percent per year. The small impact of exchange rate on prices of rice in accordance with the results obtained in the regression equation (2). If the exchange rate continues to decline in the same amount in 2020 (ceteris paribus), then in 2020 the price of rice is estimated to be Rp10,303.09 / kg, an increase of Rp 483,495 / 
Kg. From Table 3 shows that the increase in the exchange rate is greater than the absolute value of the domestic rice price decline, or increase in the exchange rate is 1.87 percent only responded by a decrease in domestic rice prices by a much smaller response, which is 0.94 percent. Likewise, the decline in the exchange rate of the same magnitude, responded smaller by the increase in domestic rice prices. In other words, the exchange rate is price-inelastic domestic rice. This condition is due to the market does not work well (not perfect) or in other words avoid distortion of the market. The increase and decrease in the exchange rate are not necessarily able to affect the price of domestic rice well, because the Indonesian rice market intervention by the government. When the rupiah appreciated, not necessarily the rice can be imported from abroad despite international rice prices are much cheaper because of imported rice is strictly regulated by the government. The second simulation is done on the variable income per capita, by raising and lowering the value of these variables by 3.9 percent. The simulation results are summarized in Table 4.

According to equation (2) that the per capita income of the domestic rice prices have a direct relationship. That is, if the level of income per capita rises, the domestic rice prices will also rise through increased demand. Conversely a decrease in per capita income will reduce the price of domestic rice. Visually, the results of this simulation are shown in Figure 8 and 9.

If the per capita income rose by 3.9 percent from 2014 (assuming the other is remain constant), then the price of rice will increase to Rp 11,168.92 / Kg in 2015. And when the per capita income levels have continued to rise by the same amount until 2020, the price of rice would be USD 22,308.58 / $\mathrm{Kg}$ in 2020. in other words, the price of rice will increase twice the price in 2015. the average increase in per capita income level of 3.9 percent per year will raise domestic rice prices by an average of 14.8 percent per year.

When Table 4 we look more closely, it would appear that the domestic rice price hike due to rising per capita income levels vary annually. In 2016, there was an increase in price by USD 1657.44 / Kg, then in 2017 the increase in the price to USD 1903.40 / $\mathrm{kg}$ from 2016, in 2018, the price increase to $\mathrm{Rp} 2185.86 / \mathrm{kg}$ and so on until 2020 an increase in the price of $\mathrm{Rp}$ 2882.74 / Kg of 2019. in other words, the period of the simulation, domestic rice price hike due to rising per capita income levels continue to rise.

Table 4. Simulation Results Increase and Decrease Income per Capita Against Domestic

Rice Price

\begin{tabular}{lll|ll}
\hline \multicolumn{3}{l}{ Income per capita increase } & & \multicolumn{2}{l}{ Income per capita decrease } \\
Year & Pd (RP) & Growth $(\%)$ & Pd (RP) & Growth (\%) \\
\hline 2015 & 11168.92 & & 8422.156 & \\
2016 & 12826.35 & 14.83974 & 7293.361 & -13.4027 \\
2017 & 14729.75 & 14.83974 & 6315.856 & -13.4027 \\
2018 & 16915.61 & 14.83974 & 5469.362 & -13.4027 \\
2019 & 19425.84 & 14.83974 & 4736.321 & -13.4027 \\
2020 & 22308.58 & 14.83974 & 4101.527 & -13.4027 \\
\hline
\end{tabular}

Source: Data Processing 


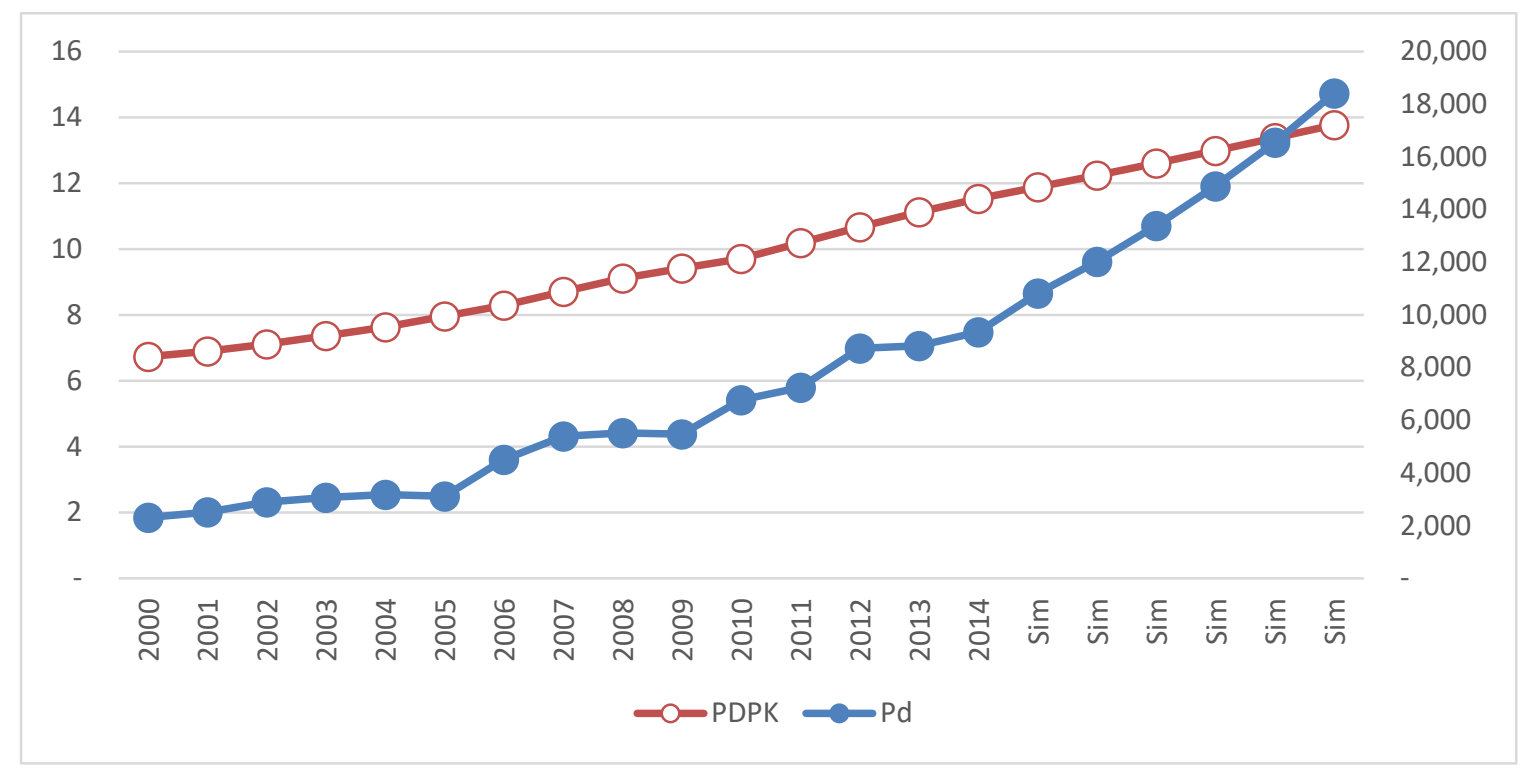

Source: Data Processing; (PDPK = income per capita; $\mathrm{Pd}=$ the domestic rice price)

Figure 8. Simulation Results Income Per Capita (Million) Against Domestic Rice Pric

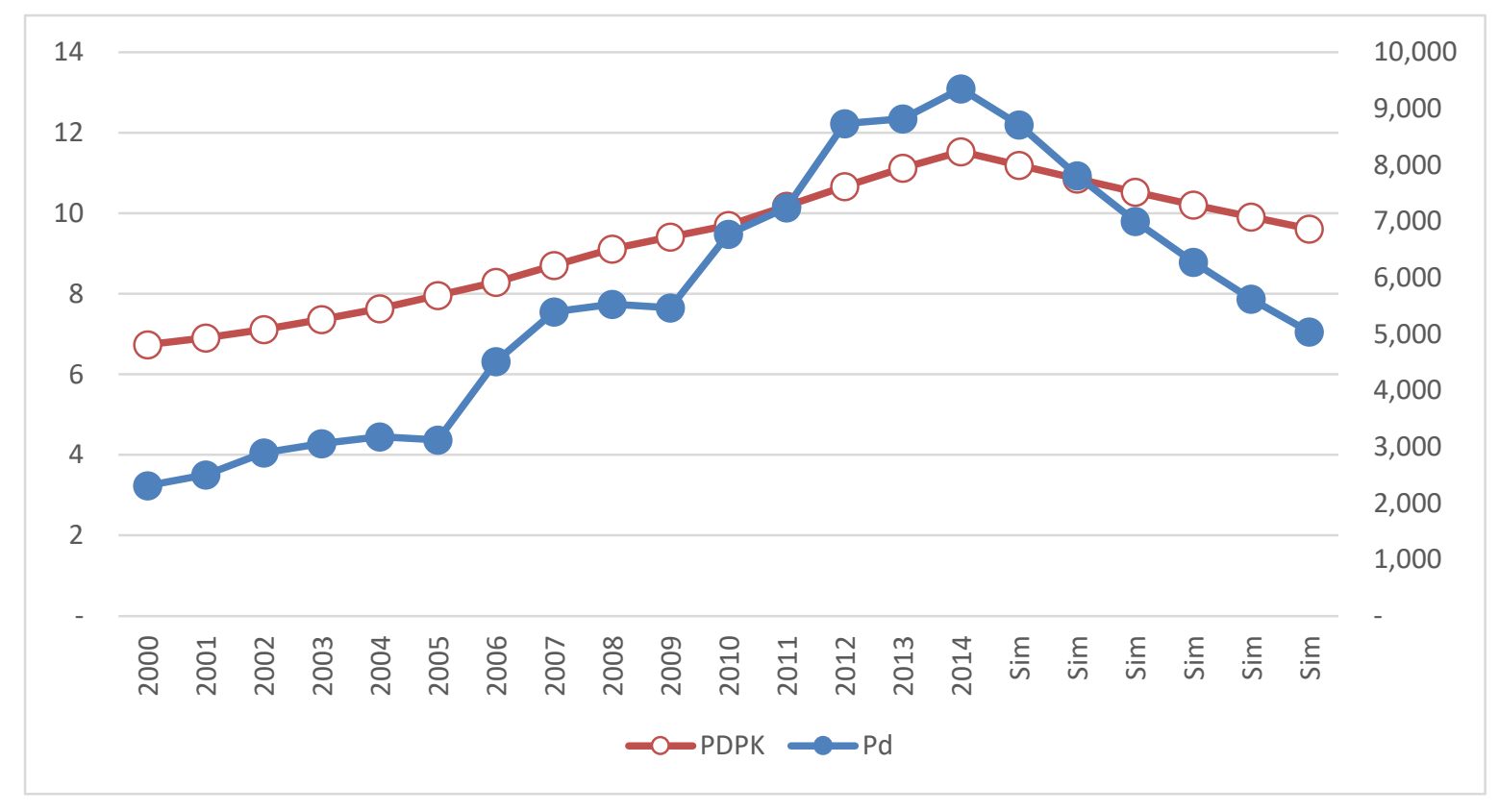

Source: Data Processing; (PDPK = income per capita; $\mathrm{Pd}=$ the domestic rice price)

Figure 9. Simulation Results Decrease in Revenue Per Capita (Million) Against Domestic Rice Price.

From figure 8 shows that the per capita income decline by an average of 3.9 percent per year would lower domestic rice prices by an average of 13.4 percent per year, assuming the others constant. If the decline in per capita income occurs continuously per year by 2020, the domestic rice price will also decrease every year until 2020. In 2020, domestic rice prices have been reduced by more than half the price in 2015, from Rp 8422, 156 / kg to $\mathrm{Rp}$ 
4,101,527 / Kg. The decline in the price of rice per year from 2014 to 2020 also varied. The highest price decrease occurred from 2014 to 2015, amounting to US \$1128.79 / kg, while in 2016 a decrease of USD 977.51 / Kg of 2015, and in 2017 decreased by $\mathrm{Rp} 846.49$ / Kg of year 2016. In 2020 the decline in prices is smaller than the previous year, amounting to $\mathrm{Rp}$ 634.79 / Kg. The simulation result shows that when per capita income continued to decline by a fixed percentage, then the price of rice will also continue to decline (due to lower levels of demand for rice), with the rate of decline in prices is getting smaller. This can be explained that the decline in household income levels will reduce the demand for rice, which eventually attractively priced to go down. However, because rice is the staple food, then at a certain level regardless of the low income households, will still require a (purchase) of rice to meet their needs. In this condition, despite the low income levels of quantity demand for rice will no longer be reduced.

\section{CONCLUSION}

From the results of the study above, we can conclude several things, as follows. Price of rice trend shows that domestic prices of rice tend to be more expensive than the price of international rice. The difference between the two prices as converging further. It needs to become the government's attention as it can be triggered an increasing rice imports, while on the other hand can be detrimental to the community are mostly role as the consumer of rice.

Variable of domestic rice production and international prices do not significantly affect the price of domestic rice, in contrast with the variable rate and per capita income levels of society. The regression results show that changes in rice production in Indonesia is not able to affect change in the price of domestic rice (not significant to the price of domestic rice). Therefore, government policies need to protect the public both as farmers and as consumers.

The rupiah exchange rate against the dollar as well as the per capita income level of the community showed a significant effect on the price of domestic rice, even level of income changes is elastic to the domestic rice price. This condition reflects the level of dependence on rice consumption of Indonesian society.

To maintain stability and affordability of domestic rice prices, the increase in the quality of infrastructure to support the sectors of rice, rice valid data provision, the efficiency of production and distribution of rice among regions should be a concern of the government. Also need proper formulation of trade policy, especially for imported rice.

\section{REFERENCES}

Arize, A, T. O and D.J. Slottje. (2008). Exchange-Rate Volatility In Latin America And Its Impact On Foreign Trade. International Review of Economics and Finance 17(1):33-44.

Asian Development Bank (ADB). (2008). Food Prices and Inflation in Developing Asia: Is Poverty Reduction Coming to an End? Economics and Research Department, Paper prepared by a team led by William E. James, ADB. April 2008.

Bowo, P., Nurayati, A., \& M. Imleesh, R. (2016). Analysis of Competitiveness and Government Policy on Rice, Corn and Soybean Farming. JEJAK: Jurnal Ekonomi Dan Kebijakan, 9(2), 159-169. doi:http://dx.doi.org/10.15294/jejak.v9i2.8235

BPS (Badan Pusat Statistik). (2013). Profil Kemiskinan di Indonesia September 2012. Berita Resmi Statistik No. 06/o1.ThXVI, 2 Januari 2013. Badan Pusat Statistik.

BPS (Badan Pusat Statistik). (2013). Profil Kemiskinan di Indonesia Maret 2013. Berita Resmi Statistik No. 47/07.Th.XVI, 1 Juli 2013. Badan Pusat Statistik.

De Hoyos, R. E. and Medvedev, D. (2009). Poverty Effects of Higher Food Prices: A Global Prospective. Policy 
Research Working Paper No. 4887. The World Bank, Washington DC.

Haque, A.K. Iftrkharul. (2012). The Effect of Exchange Rate and Commodity Price Volatilities on Trade Volumes of Major Agricultural Commodities. A Thesis. University of Guelph, Canada.

Hung, Nguyen Manh, and Paul Makdissi. (2004) . Escaping the Poverty trap in a Developing Rural Economy. The Canadian Journal of economics/Revue Canadienned'Economique. Vol. 37(1). Feb, 2004: 123-139.

IFPRI. (2011). 2011 Global Food Policy Report. Washington, D.C.: International Food Policy Research Institute.

Jantan, M. D., I. Maipita, Fitrawaty, dan I. Hamdani. (2012). The Impact of Diverting a Fuel Subsidy to the Agricultural Sector on Income Distribution and Poverty. The International Journal of Interdiciplinary Environmental Studies 7(2): 1-13.

Kandilov, I. (2008). The Effects of Exchange Rate Volatility on Agricultural Trade. American Journal of Agricultural Economics 90(4): 10281043.

Kementerian Perdagangan RI. (2015). Laporan Akhir Analisis Dampak Kebijakan Pemerintah terhadap Inflasi dan Kemiskinan. Pusat Kebijakan Perdagangan dalam Negeri. Badan Pengkajian dan Pengembangan kebijakan Perdagangan Kementerian Perdagangan RI.

Kementerian Perdagangan RI. (2015a). Laporan Akhir Kajian Efektivitas Kebijakan Impor Produk Pangan Dalam Rangka Produk Pangan. Pusat Kebijakan Perdagangan dalam Negeri. Badan Pengkajian dan Pengembangan kebijakan Perdagangan Kementerian Perdagangan RI.

Maipita, Indra. (2014). Mengukur Kemiskinan dan Distribusi Pendapatan. Yogyakarta: UPP STIM YKPN.

Maipita, Indra., Moh. Dan Jantan., and Nor Azam Abdul Razak. (2010). The Impact of Fiscal Policy Toward Economic Performance and Poverty Rate in Indonesia. Bulletin of Monetary Ecomomics and Banking, Bank Indonesia 12(4): 391-424.

Maipita, Indra., Wawan Hermawan, dan Fitrawaty. (2012). Reducing Poverty Through Subsi- dies: Simulation of Fuel Subsidy Diver- tion to NonFood Crops. Bulletin of Monetary Ecomomics and Banking, Bank Indonesia 14(4):369-387.

Maipita, Indra., Wawan Hermawan, Fitrawaty, and Budi Eko Soetjipto. (2016). The Impact of Middle Class Spending on Economic Growth and Industry in
Indonesia. International Journal of Economics Research. Serial Publication. Vol. 13(3): 813-828.

Marianti, R, dan wawan Munawar, W. (2006). Moving Out of Poverty: The case of Desa Branta Pesisir, Pamekasan Regency. SEMERU Research Institute.

Minot, N. and Goletti, F. (200o). Rice Market Liberalization and Poverty in VietNam. Research Report 114, International Food Policy Research Institute, Washington DC.

Moller, Stephanie., evelyne Huber, John D. Stephens, David Bradley, and Francois Nielson. (2003). Determinant of relative Poverty in Advanced Capitalist Democracies. American Sociological Review, Vol. 68(1): 22-51.

$\mathrm{MP}_{3} \mathrm{EI}$, Kementerian Koordinator Bidang Perekonomian. 2011. MasterPlan Percepatan dan Perluasan Pembangunan Ekonomi Indonesia 2011-2025 (MP3EI). Kementerian koordinator Bidang Perekonomian Republik Indonesia.

OECD. (2015). OECD Economic Survey: Indonesia 2015.

Ravallion, M. and van der Walle, D. (1991). The Impact on Poverty of Food Pricing Reforms: a Welfare Analysis for Indonesia. Journal of Policy Modeling13(2): 28199 .

Save the Children, (2009). How the Global Food Crisis is Hurting Children: The Impact of the Food Price Hike on a Rural Community in Northern Bangladesh. Save the Children UK, London.

Shrestha M.D, and Chaudhary, S.K. (2012). The Impact of Food Inflation on Poverty in Nepal. NBR Economic Review.

Syaifullah, Yunan. (2013). Ketahanan Pangan dan Pola Distribusi Beras di Propinsi Jawa Timur. JEJAK Journal of Economics and Policy, 6 (2): 103-213 doi: 10.15294jejak.v7i1.3596.

Timmer, C. (2014), Rice price stabilization in Indonesia: A century-long perspective (Stabilisasi harga beras di Indonesia: Perspektif satu abad), presentasi dalam konferensi Bank Dunia Volatilitas Harga Pangan, Ketahanan Pangan dan Kebijakan Perdagangan, 1819 September.

Tulasombat, Sirikul., Chanchai Bunchapattanasakda, Somchai Ratanakomut. (2015). The Effect on Exchange Rates on Agricultural Goods for Export: A Case of Thailand. Information Management and Business Review. Vol. 7(1): 1-11.

Wailes, Eric J., Eddie C. Chaves. (2012). ASEAN and Global Rice Situiation and Outlook. ADB Sustainable Development Working Paper Series. No.2. Agustus 2012.

Widayaningsih, N., \& Barokatuminalloh, B. (2016). Strategy of Increasing Food Security based on Macro and Micro Aspects. JEJAK: Jurnal Ekonomi Dan 
Kebijakan, 9(1): 111-128.

World Bank. (2010). Perkembangan Triwulan Perekonomian Indonesia: Melihat ke Masa Depan. The World Bank.

World Bank.(2008). Rising Food and Fuel Prices: Addressing the Risks to Future Generations. World Bank, Washington DC. 